\title{
Pengaruh motivasi berprestasi dan persepsi siswa tentang cara guru mengajar terhadap hasil belajar matematika siswa
}

\author{
Wulandari $^{*}$, Syahrul Azmi ${ }^{2}$, Nani Kurniati², Nurul Hikmah² \\ ${ }^{1}$ Mahasiswa Pendidikan Matematika, FKIP, Universitas Mataram, Mataram \\ 2 Pendidikan Matematika, FKIP, Universitas Mataram, Mataram \\ wulandari.mtk15@gmail.com
}

Diterima: 26-09-2021; Direvisi: 29-09-2021; Dipublikasi: 30-09-2021

\begin{abstract}
This study aims to: (1) find out how achievement motivation affects the mathematics learning outcomes; (2) knowing how the influence by student perceptions of how teachers teach on mathematics learning outcomes; and (3) to find out how the influence of achievement motivation and student perceptions about how teachers teach on the mathematics learning outcomes at VIII grade students of SMPN 16 Mataram in academic year 2019/2020. This type of research is ex post facto research. The population of this study were all students at VIII grade as many as 110 students consisting of classes A, B, C and D. The sample used was saturated sampling where the entire population was the sample in this study. The data collection technique used was a questionnaire and tests. This research uses prerequisite test analysis techniques and inferential analysis techniques. The results obtained show: (a) There is a significant effect of achievement motivation on the mathematics learning outcomes with a contribution of $10.1 \%$; (b) there is a significant influence on student perceptions of how teachers teach on mathematics learning outcomes with a contribution of $17.8 \%$; and (c) there is a significant influence on achievement motivation and student perceptions of how teachers teach on mathematics learning outcomes with a contribution of $20.1 \%$.
\end{abstract}

Keywords: achievement motivation; students' perceptions; mathematics learning outcomes

\begin{abstract}
Abstrak
Penelitian ini bertujuan untuk: (1) mengetahui bagaimana pengaruh motivasi berprestasi terhadap hasil belajar matematika; (2) mengetahui bagaimana pengaruh persepsi siswa tentang cara guru mengajar terhadap hasil belajar matematika siswa kelas VIII SMPN 16 Mataram tahun ajaran 2019/2020; dan (3) mengetahui bagaimana pengaruh motivasi berprestai dan persepsi siswa tentang cara guru mengajar terhadap hasil belajar matematika siswa kelas VIII SMPN 16 Mataram tahun ajaran 2019/2020. Jenis penelitian yang digunakan adalah penelitian ex post facto. Populasi dari penelitian ini seluruh siswa kelas VIII sebanyak 110 siswa yang terdiri dari kelas A, B, C dan D. Sampel yang digunakan adalah sampling jenuh dimana seluruh populasi menjadi sampel pada penelitian ini. Teknik pengumpulan data yang digunakan adalah angket dan tes. Metode penelitian ini menggunakan uji prasyarat dan teknik analisis inferensial. Hasil penelitian yang diperoleh menujukkan: (a) Terdapat pengaruh yang signifikan motivasi berprestasi terhadap hasil belajar matematika siswa dengan kontribusi sebesar 10,1\%; (b) terdapat pengaruh yang signifikan persepsi siswa tentang cara guru mengajar terhadap hasil belajar matematika siswa dengan kontribusi sebesar 17,8\%; dan (c) terdapat pengaruh yang signifikan motivasi berprestasi dan persepsi siswa tentang cara guru mengajar terhadap hasil belajar matematika siswa dengan kontribusi sebesar $20,1 \%$.
\end{abstract}

Kata Kunci: motivasi berprestasi; persepsi siswa; hasil belajar matematika 


\section{PENDAHULUAN}

Proses belajar mengajar terjadi dalam kehidupan. Menurut Sadirman dari proses belajar mengajar ini akan diperoleh suatu hasil, yang pada umunya disebut hasil pengajaran, atau dengan istilah tujuan pembelajaran atau hasil belajar. Tetapi agar memperoleh hasil yang optimal, proses belajar mengajar harus dilakukan dengan sadar dan sengaja serta terorganisasi secara baik (Sudirman, 2011).

Keberhasilan belajar peserta didik tidak terlepas dari faktor proses. Proses belajar mengajar merupakan salah satu faktor dominan yang mempengaruhi hasil belajar siswa dan kualitas pendidikan yang digerakkan oleh guru. Guru sangat memegang peranan penting dalam menentukan arah dan keberhasilan siswa mempelajari suatu mata pelajaran. Guru yang berbakat dalam mengajar dapat mentransfer pengetahuan yang ada pada dirinya lebih mudah kepada siswa daripada guru yang tidak berbakat. Sahidin \& Jamil, menyatakan guru yang berbakat ditandai dengan kemampuannya dalam menggunakan metode mengajar, mengatur waktu, disiplin, ramah, mimik yang selalu menarik dan simpatik. Selain peranan guru, motivasi dalam diri siswa untuk berprestasi juga mempengaruhi hasil belajarnya (Sahidin et al., 2013).

Priansa menyatakan motivasi merupakan keseluruhan daya penggerak di dalam diri peserta didik yang menimbulkan kegiatan belajar, yang menjamin kelangsungan kegiatan belajar serta memberikan arah pada kegiatan belajar sehingga tujuan pembelajaran y.ang dikehendaki oleh peserta didik dapat tercapai (Priansa, 2017). Sedangkan menurut Nasution motivasi berprestasi merupakan suatu dorongan atau keinginan dalam diri untuk mencapai kesuksesan yang setinggi mungkin sehingga tercapai kecakapan pribadi yang tinggi, sehingga individu berusaha keras dengan sebaik-baiknya dalam pencapaian prestasi di bidang akademik (Nasution, 2017). Siswa yang mempunyai motivasi berprestasi yang baik ditandai dengan beberapa hal yaitu: siswa tersebut tanggap terhadap tantangan terutama dalam belajar, rasional dalam berpikir, bertanggung jawab dalam hal ini selalu bersikap jujur dan bersemangat dalam belajar, berusaha unggul dalam kelompok, dan selalu dapat menyesuaikan diri bila ia berinteraksi dengan teman-temannya. Selain itu hal yang juga berperan dalam peningkatan motivasi berprestasi siswa adalah guru itu sendiri. Boleh jadi siswa mempunyai semangat yang tinggi dalam belajar tapi kerena gurunya yang kurang baik dalam memberikan perhatian dan penghargaan kepada siswa, maka motivasi belajar siswa menjadi menurun yang berimplikasi pada rendahnya hasil belajar matematika siswa (Sahidin et al., 2013).

Berdasarkan hasil observasi dan wawancara yang peneliti lakukan pada siswa kelas VIII di SMPN 16 Mataram diketahui, siswa yang memiliki prestasi tinggi dikelas cenderung beranggapan bahwa penyampaian materi yang dilakukan guru sudah baik sehingga membuat siswa mudah untuk memahami materi pembelajaran yang diajarkan, merespon pertanyaan siswa dengan baik, serta sikap guru yang ramah tetapi tetap tegas membuat beberapa siswa menjadi senang untuk mengikuti pembelajaran 
matematika di kelas. Namun disisi lain, beberapa siswa yang prestasinya tergolong biasa saja dan rendah beranggapan bahwa, cara mengajar guru terlalu cepat dan kurang dipahami oleh mereka, guru kurang mendengarkan dan menanggapi kesulitankesulitan yang dialami mereka dalam pembelajaran, serta beberapa siswa yang beranggapan bahwa guru matematika mereka terkesan galak dan membosankan. Dari hasil wawancara tersebut terlihat bahwa persepsi siswa tentang cara guru mengajar antara siswa yang memiliki hasil belajar tinggi, sedang dan rendah berbeda-beda.

Walgito persepsi merupakan suatu proses yang didahului oleh proses penginderaan, yaitu merupakan proses diterimanya rangsangan oleh individu melalui olat indera atau juga disebut sensoris (Bimo, 2010). Menurut Desmita (2012), meskipun persepsi bergantung pada indra manusia, proses koognitif yang ada pada diri manusia akan memungkinkan terjadinya proses penyaringan, perubahan atau modifikasi dari stimulus yang ada. Dari pernyataan tersebut dapat dipahami bahwa persepsi timbul sebagai akibat proses penerimaan dan pamaksaan stimulus yang diterima individu melalui panca indra sehingga persepsi itu timbul dengan sendirinya melaiankan ada proses yang menyebabkan adanya persepsi.

\section{METODE PENELITIAN}

Jenis penelitian yang digunakan adalah penelitian ex post facto. Penelitian ini dilaksanakan di SMPN 16 Mataram. Pengambilan data penelitian dilaksanakan pada tanggal 12 Februari 2020 di SMP Negeri 16 Mataram dengan populasi seluruh siswa kelas VIII yang berjumlah 110 siswa. Sampel dalam penelitian ini berjumlah 110 siswa. Teknik pengambilan sampel adalah sampling jenuh, karena semua populasi digunakan sebagai sampel. Pengambilan data dilakukan dengan membagikan angket motivasi berprestasi dengan pernyataan berjumlah 25 pernyataan dan angket persepsi siswa tentang cara guru mengajar dengan pernyataan berjumlah 20 pernyataan pada pertemuan pertama.

Selanjutnya, pengambilan data dengan tes berbentuk esai yang berjumlah 10 soal untuk mengetahui hasil belajar matematika siswa dilakukan pada pertemuan kedua tanggal 17 Februari 2020. Data penelitian diperoleh dengan menggunakan instrumen berupa angket motivasi berprestasi dan angket persepsi siswa tentang cara guru mengajar, serta tes untuk nilai hasil belajar matematika siswa. Teknik analisis data yang digunakan dalam penelitian ini adalah teknik analisis statistik inferensial. Selanjutnya dilakukan analisis statistik inferensial, yaitu analisis korelasi, analisisi regresi, Uji t, Uji F dan koefisien determinasi.

\section{HASIL DAN PEMBAHASAN}

\subsection{Hasil}

\subsubsection{Uji Prasyarat}

Berdasarkan hasil Uji Prasyarat, diperoleh data siswa sebagai berikut: 
Tabel 1. Hasil Analisis Uji Normalitas One-Sample Kolmogorov-Smirnov Test

\begin{tabular}{|c|c|c|c|c|}
\hline & & $\begin{array}{c}\text { Motivasi } \\
\text { berprestasi }\end{array}$ & $\begin{array}{c}\text { Persepsi siswa } \\
\text { tentang cara guru } \\
\text { mengajar }\end{array}$ & $\begin{array}{c}\text { Hasil } \\
\text { belajar }\end{array}$ \\
\hline $\mathrm{N}$ & & 110 & 110 & 110 \\
\hline Normal & Mean & 78,25 & 62,59 & 44,43 \\
\hline & Std. Deviasi & 10,049 & 7,873 & 19,288 \\
\hline Most Extreme & Absolute &, 100 & ,093 & ,105 \\
\hline & Positive & ,099 & ,093 &, 105 \\
\hline & Negative &,- 100 & -043 &,- 059 \\
\hline $\begin{array}{l}\text { Kolmogorov- } \\
\text { Smirnov Z }\end{array}$ & & 1,050 & ,971 & 1,096 \\
\hline $\begin{array}{l}\text { Asymp. Sig (2- } \\
\text { tailed) }\end{array}$ & & 220 & ,302 & , 181 \\
\hline
\end{tabular}

Hasil uji normalitas yang dilakukan, diperoleh nilai signifikansi dari data motivasi berprestasi adalah 0,220, nilai signifikansi dari data persepsi siswa tentang cara guru mengajar adalah 0,302, dan nilai signifikansi dari data hasil belajar matematika adalah 0,181, dimana nilai signifikansi dari ketiga data tersebut lebih dari 0,05. Berdasarkan hal tersebut, maka data hasil skor kuesioner motivasi berprestasi, skor kuesioner persepsi siswa tentang cara guru mengajar, dan nilai hasil belajar matematika siswa berdistribusi normal.

Tabel 2. Hasil Analisis Uji Linearitas Motivasi Berprestasi Terhadap Hasil Belajar Matematika

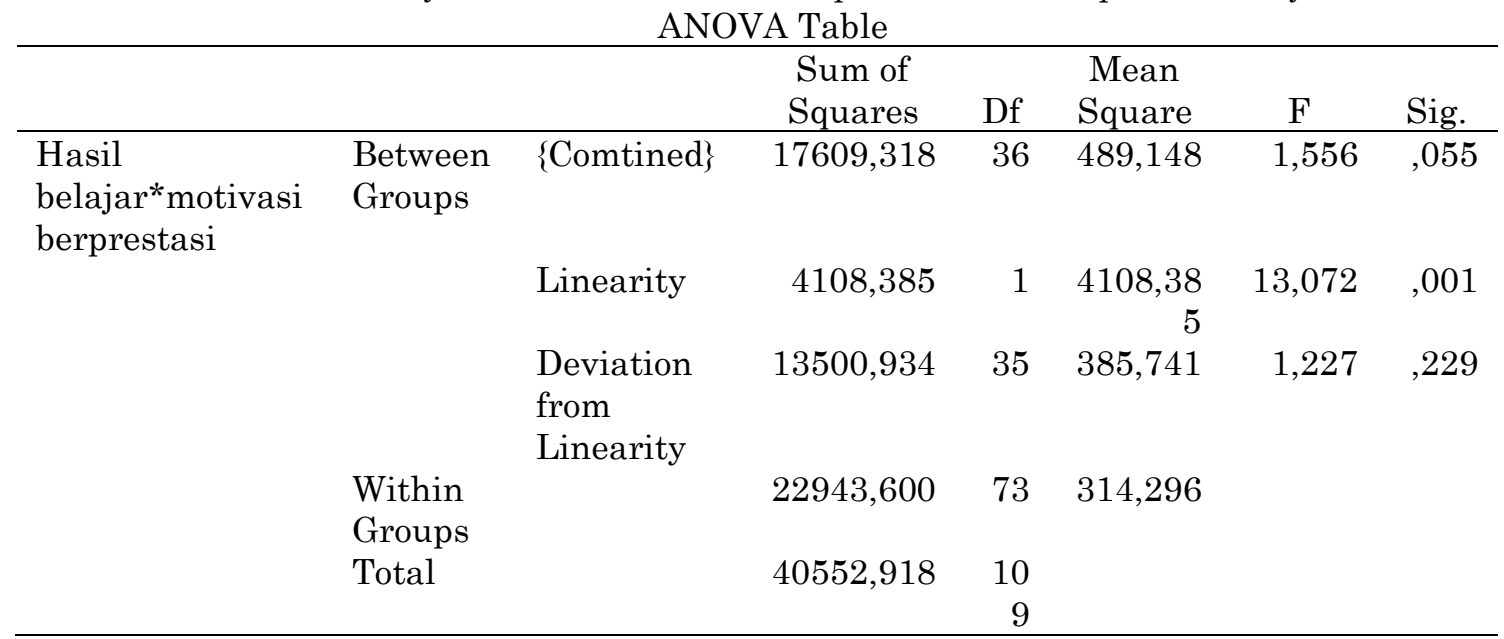

Hasil Uji Linearitas dengan menggunakan SPSS 21 diketahui nilai signifikan 0,229 > 0,05 maka ditarik kesimpulan bahwa terdapat hubungan yang linear antara motivasi berprestasi terhadap hasil belajar matematika. 
Tabel 3. Hasil Analisis Uji Linearitas Persepsi siswa tentang cara guru mengajar terhadap hasil belajar matematika (ANOVA Table)

\begin{tabular}{|c|c|c|c|c|c|c|c|}
\hline & & & $\begin{array}{c}\text { Sum of } \\
\text { Squares }\end{array}$ & $\mathrm{df}$ & $\begin{array}{c}\text { Mean } \\
\text { Square }\end{array}$ & $\mathrm{F}$ & Sig. \\
\hline \multirow{5}{*}{$\begin{array}{l}\text { Hasil } \\
\text { belajar*persepsi } \\
\text { siswa tentang } \\
\text { cara guru } \\
\text { mengajar }\end{array}$} & $\begin{array}{l}\text { Between } \\
\text { Groups }\end{array}$ & $\{$ Comtined $\}$ & 19170,571 & 30 & 639,019 & 2,361 &, 001 \\
\hline & & Linearity & 7203,003 & 1 & 7203,003 & 26,612 & ,000 \\
\hline & & $\begin{array}{l}\text { Deviation } \\
\text { from } \\
\text { Linearity }\end{array}$ & 11967,567 & 29 & 412,675 & 1,525 & 073 \\
\hline & $\begin{array}{l}\text { Within } \\
\text { Groups }\end{array}$ & & 21382,348 & 79 & 270,663 & & \\
\hline & Total & & 40552,918 & 109 & & & \\
\hline
\end{tabular}

Hasil Uji Linearitas dengan menggunakan SPSS 21 diketahui nilai signifikan 0,073>0,05 maka ditarik kesimpulan bahwa terdapat hubungan yang linear antara persepsi siswa tentang cara guru mengajar terhadap hasil belajar matematika.

Tabel 4. Hasil Uji multikolinearitas (Coefficientsa)

\begin{tabular}{|c|c|c|c|c|c|c|c|c|}
\hline & & \multicolumn{2}{|c|}{$\begin{array}{c}\text { Unstandardized } \\
\text { Coefficients }\end{array}$} & \multirow{2}{*}{$\begin{array}{c}\text { Standardized } \\
\text { Coefficients }\end{array}$} & \multirow[t]{2}{*}{$\mathrm{t}$} & \multirow[t]{2}{*}{ Sig. } & \multicolumn{2}{|c|}{$\begin{array}{c}\text { Colinearity } \\
\text { Statistics }\end{array}$} \\
\hline & & B & Std.Error & & & & $\begin{array}{c}\text { Tolera } \\
\text { nce }\end{array}$ & $\mathrm{VF}$ \\
\hline \multirow[t]{3}{*}{1} & (Constant) & $-34,532$ & 15,616 & & $-2,211$ &, 029 & & \\
\hline & $\begin{array}{l}\text { Motivasi } \\
\text { berprestasi }\end{array}$ & ,325 & ,183 & ,169 & 1,770 & ,079 & ,818 & 1,223 \\
\hline & $\begin{array}{l}\text { Persepsi } \\
\text { siswatentan } \\
\text { g cara guru } \\
\text { mengajar }\end{array}$ & ,856 & ,234 &, 349 & 3,654 &, 000 & ,818 & 1,223 \\
\hline
\end{tabular}

Hasil Uji Multikolinearitas dengan menggunakan program SPSS 21 diketahui nilai VIF $1,223 \leq 10$ maka ditarik kesimpulan bahwa tidak terjadi multikolinearitas antara variabel independen yaitu motivasi berprestasi dan persepsi siswa tentang cara guru mengajar.

\subsubsection{Hasil Analisis Inferensial}

Berdasarkan Tabel 5 diperoleh nilai $a=-3,378$ dan $b=0,611$ dengan persamaan regresi sederhana $Y=a+b X$, sehingga persamaan regresi motivasi berprestasi terhadap hasil belajar yaitu $Y=-3,378+0,611 X$. Hasil pengujian hipotesis pada Tabel 5 dapat dilihat pada nilai sig motivasi berprestasi yaitu 0,001 dimana nilai sig $<0,05$, sehingga $H_{0}$ ditolak yang artinya "terdapat pengaruh yang signifikan motivasi berprestasi terhadap hasil belajar matematika pada siswa kelas VIII SMPN 16 Mataram Tahun Ajaran 2019/2020". 
Tabel 5. Hasil Uji Parsial/Uji T Motivasi Berprestasi Terhadap Hasil Belajar Matematika (Coefficientsa)

\begin{tabular}{|c|c|c|c|c|c|c|}
\hline \multirow[t]{2}{*}{ Model } & & \multicolumn{2}{|c|}{$\begin{array}{l}\text { Unstandardized } \\
\text { Coefficients }\end{array}$} & \multirow{2}{*}{$\begin{array}{c}\begin{array}{c}\text { Standardized } \\
\text { Coefficients }\end{array} \\
\text { Beta }\end{array}$} & \multirow[t]{2}{*}{$\mathrm{T}$} & \multirow[t]{2}{*}{ Sig. } \\
\hline & & B & Std. Error & & & \\
\hline & (Constant) & -3.378 & 13,812 & &,- 245 & ,807 \\
\hline 1 & $\begin{array}{l}\text { Motivasi } \\
\text { Berprestasi }\end{array}$ & ,611 & ,175 & 318 & 3,489 & , 001 \\
\hline
\end{tabular}

Nilai koefisien determinasi secara parsial (R-Square) yang ditunjukkan pada Tabel 6 menujukkan besarnya pengaruh yang diberikan motivasi berprestasi terhadap hasil belajar matematika yaitu sebesar 10,1\%. Dari hasil tersebut, dapat diartikan bahwa semakin tinggi motivasi berprestasi, maka semakin tinggi pula hasil belajar matematikanya. Sebaliknya, jika semakin rendah motivasi berprestasi, maka semakin rendah pula hasil belajar matematika yang akan dicapai.

Tabel 6. Hasil Koefisien Determinasi Variabel Motivasi Berprestasi Terhadap Hasil Belajar

\begin{tabular}{lrrrr}
\multicolumn{5}{c}{ Matematika (Model Summary) } \\
\hline Model & $\mathrm{R}$ & $\mathrm{R}$ Square & $\begin{array}{c}\text { Adjusted R } \\
\text { Square }\end{array}$ & $\begin{array}{r}\text { Std. Error of } \\
\text { the Estimate }\end{array}$ \\
\hline 1 &, $318^{\mathrm{a}}$ &, 101 &, 093 & 18,370 \\
\hline
\end{tabular}

Hasil penelitian ini didukung oleh teori yang dikemukakan oleh Purwanto (2013), yaitu motivasi berprestasi merupakan salah satu faktor yang ikut menentukan keberhasilan dalam belajar. Menurut Mc Clelland (Sahidin et al., 2013) mendefinisikan motivasi berprestasi sebagai suatu usaha untuk mencapai sukses, yang bertujuan untuk berhasil dalam kompetisi dengan suatu ukuran keunggulan. Oleh karena itu motivasi berprestasi siswa perlu ditingkatkan untuk meningkatkan hasil belajar siswa.

Berdasarkan Tabel 7 diperoleh nilai $a=20,198$ dan $b=1,033$ dengan persamaan regresi sederhana $Y=a+b X$, sehingga persamaan regresi lingkungan belajar terhadap hasil belajar yaitu $Y=20,198+1,033 X$. Hasil pengujian hipotesis pada Tabel 7 dapat dilihat pada nilai sig persepsi siswa tentang cara guru mengajar terhadap hasil belajar matematika yaitu 0,000 dimana nilai sig $<0,05$, yang artinya "terdapat pengaruh yang signifikan persepsi siswa tentang cara guru mengajar terhadap hasil belajar matematika terhadap hasil belajar matematika pada siswa kelas VII SMP Negeri 16 Mataram Tahun Ajaran 2019/2020”.

Tabel 7. Hasil Uji Parsial/Uji t Persepsi Siswa Tentang Cara Guru Mengajar Terhadap Hasil Belajar Matematika (Coefficientsa)

\begin{tabular}{llrrrrr}
\hline Model & \multicolumn{2}{c}{$\begin{array}{c}\text { Unstandardized } \\
\text { Coefficients }\end{array}$} & $\begin{array}{c}\text { Standardized } \\
\text { Coefficients }\end{array}$ & & \multirow{2}{*}{ Sig. } \\
\cline { 2 - 4 } & \multicolumn{1}{c}{ B } & Std. Error & Beta & & \\
\hline $\begin{array}{l}\text { (Constant) } \\
\text { Persepsi siswa } \\
\text { tentang cara } \\
\text { guru mengajar }\end{array}$ & $-20,198$ & 13,485 & & & $-1,498$ &, 137 \\
\hline
\end{tabular}


Nilai koefisien determinasi secara parsial (R Square) yang ditunjukkan pada Tabel 8 menujukkan besarnya pengaruh yang diberikan lingkungan belajar terhadap hasil belajar matematika yaitu sebesar 17,8\%. Dari hasil tersebut, dapat diartikan bahwa semakin tinggi persepsi siswa tentang cara guru mengajar, maka semakin tinggi pula hasil belajar matematikanya. Sebaliknya, jika semakin rendah persepsi siswa tentang cara guru mengajar siswa, maka semakin rendah pula hasil belajar matematika yang akan dicapai.

Tabel 8. Hasil Koefisien Determinasi Variabel Persepsi Siswa Tentang Cara Guru Mengajar Terhadap Hasil Belajar Matematika (Model Summary)

\begin{tabular}{ccccc}
\hline Model & $\mathrm{R}$ & $\mathrm{R}$ Square & $\begin{array}{c}\text { Adjusted R } \\
\text { Square }\end{array}$ & $\begin{array}{c}\text { Std. Error of } \\
\text { the Estimate }\end{array}$ \\
\hline 1 &, $421^{\mathrm{a}}$ &, 178 &, 170 & 17,578 \\
\hline
\end{tabular}

Berdasarkan Tabel 7 diperoleh nilai $a=20,198$ dan $b=1,033$ dengan persamaan regresi sederhana $Y=a+b X$, sehingga persamaan regresi lingkungan belajar terhadap hasil belajar yaitu $Y=20,198+1,033 X$. Hasil pengujian hipotesis pada Tabel 7 dapat dilihat pada nilai sig persepsi siswa tentang cara guru mengajar terhadap hasil belajar matematika yaitu 0,000 dimana nilai sig $<0,05$, yang artinya "terdapat pengaruh yang signifikan persepsi siswa tentang cara guru mengajar terhadap hasil belajar matematika terhadap hasil belajar matematika pada siswa kelas VII SMP Negeri 16 Mataram Tahun Ajaran 2019/2020". Nilai koefisien determinasi secara parsial (R Square) yang ditunjukkan pada Tabel 8 menujukkan besarnya pengaruh yang diberikan lingkungan belajar terhadap hasil belajar matematika yaitu sebesar 17,8\%. Dari hasil tersebut, dapat diartikan bahwa semakin tinggi persepsi siswa tentang cara guru mengajar, maka semakin tinggi pula hasil belajar matematikanya. Sebaliknya, jika semakin rendah persepsi siswa tentang cara guru mengajar siswa, maka semakin rendah pula hasil belajar matematika yang akan dicapai.

Hasil penelitian ini didukung oleh teori yang dikemukakan oleh Purwanto (2013) bahwa salah satu faktor eksternal yang mempengaruhi hasil belajar adalah guru/pengajar atau cara guru mengajar. Menurut Desmita (2021) persepsi diawali dengan adanya rangsangan dari lingkngan sekitarnya yang ditangkap oleh panca indra, stimulus yang telah ditangkap kemudian akan diterjemahkan oleh otak untuk dapat menginterpretasikan dan menyaring informasi yang diperlukan. Hasil pemaknaan inilah yang membentuk persepsi individu.

Berdasarkan Tabel 9 diperoleh nilai $a$ sebesar -34,532 dan $b_{1}=0,325, b_{2}=0,856$ dengan persamaan regresi berganda yaitu $Y=a+b_{1} X_{1}+b_{2} X_{2}$, sehingga diperoleh persamaan regresinya yaitu: $\mathrm{Y}^{\wedge}=-34,532+0,325 X_{1}+0,856 X_{2}$. Hasil perhitungan pada tabel 3.10 diperoleh nilai sig sebesar 0,000 dimana nilai sig $<0,05$ Sehingga dapat disimpulkan bahwa "terdapat pengaruh yang signifikan motivasi berprestasi dan persepsi siswa tentang cara guru mengajar terhadap hasil belajar matematika siswa kelas VIII SMPN 16 Mataram Tahun Ajaran 2019/2020". 
Tabel 9. Hasil Analisis Regresi Motivasi Berprestasi dan Persepsi Siswa Tentang Cara Guru Mengajar Terhadap Hasil Belajar Matematika (Coefficientsa)

\begin{tabular}{|c|c|c|c|c|c|c|}
\hline \multirow{2}{*}{\multicolumn{2}{|c|}{ Model }} & \multirow{2}{*}{\multicolumn{2}{|c|}{$\begin{array}{c}\text { Unstandardized } \\
\text { Coefficients }\end{array}$}} & \multirow{2}{*}{$\begin{array}{l}\text { Standardized } \\
\text { Coefficients }\end{array}$} & \multirow[t]{2}{*}{$\mathrm{T}$} & Sig. \\
\hline & & & & & & \\
\hline \multirow{6}{*}{1} & (Constant) & -34.532 & 15616 & & - 211 & 090 \\
\hline & Motivasi & .325 & 183 & 169 & 1770 & 079 \\
\hline & berprestasi & & & & & \\
\hline & Persepsi siswa & & & & & \\
\hline & tentang cara guru & ,856 & ,234 & 349 & 3,654 & ,000 \\
\hline & $\begin{array}{l}\text { mengajar terhadap } \\
\text { hasil }\end{array}$ & & & & & \\
\hline
\end{tabular}

Tabel 10. Hasil Uji F Motivasi Berprestasi dan Persepsi Siswa Tentang Cara Guru Mengajar Terhadap Hasil Belajar Matematika (ANOVAa)

\begin{tabular}{llcccrr}
\hline Model & $\begin{array}{c}\text { Sum of } \\
\text { Squares }\end{array}$ & Df & $\begin{array}{c}\text { Mean } \\
\text { Square }\end{array}$ & F & Sig. \\
\hline \multirow{4}{*}{1} & Regressio & 8152,170 & 2 & 4076,085 & 13,46 &, $000^{\mathrm{b}}$ \\
$\mathrm{n}$ & & & & 1 & \\
& Residual & 32400,748 & 107 & 302,811 & & \\
& Total & 40552,918 & 109 & & & \\
\hline
\end{tabular}

Nilai koefisien determinasi ( $R$ Square) yang ditunjukkan pada Tabel 11 menujukkan besarnya variabel motivasi berprestasi dan persepsi siswa tentang cara guru mengajar terhadap hasil belajar matematika sebesar 0.201 atau 20,1\%. Artinya, variabel motivasi berprestasi dan persepsi siswa tentang cara guru mengajar secara bersama-sama memengaruhi hasil belajar siswa pada mata pelajaran matematika sebesar 20,1\%, sedangkan sisanya 79,9\% dipengaruhi oleh faktor lain. Dari hasil tersebut, dapat diartikan bahwa semakin tinggi motivasi berprestasi, maka semakin tinggi pula hasil belajar matematikanya. Sebaliknya, jika semakin rendah motivasi berprestasi, maka semakin rendah pula hasil belajar matematika yang akan dicapai.

Tabel 11. Hasil Koefisien Determinasi Secara Simultan (Model Summary)

\begin{tabular}{ccccc}
\hline Model & $\mathrm{R}$ & $\mathrm{R}$ Square & $\begin{array}{c}\text { Adjusted R } \\
\text { Square }\end{array}$ & $\begin{array}{c}\text { Std. Error of } \\
\text { the Estimate }\end{array}$ \\
\hline 1 &, $448^{\mathrm{a}}$ &, 201 &, 186 & 17,401 \\
\hline
\end{tabular}

Hasil penelitian ini sejalan dengan pendapat Slameto (2010) yang menyatakan bahwa ada faktor-faktor yang dapat mempengaruhi motivasi berprestasi, yaitu faktor yang pertama, dorongan kognitif adalah kebutuhan untuk mengetahui, untuk mengerti, dan untuk memecahkan masalah. Dorongan kognitif timbul di dalam proses interaksi antara siswa dengan tugas/masalah. Kedua, harga diri Ada siswa tertentu yang tekun belajar melaksanakan tugas-tugas bukan terutama untuk memperoleh pengetahuan atau kecakapan, melainkan untuk memperoleh status dan harga diri. Dan yang ketiga, Kebutuhan berafiliasi sukar dipisahkan dari harga diri. Ada siswa yang berusaha menguasai bahan pelajaran atau belajar dengan giat untuk memperoleh pembenaran/ penerimaan dari teman-temannya atau dari orang lain (atasan) yang dapat memberikan status kepadanya. 


\subsection{Pembahasan}

Penelitian ini merupakan penelitian expo facto yang bertujuan untuk melihat pengaruh motivasi berprestasi dan persepsi siswa tentang cara guru mengajar terhadap hasil belajar matematika siswa kelas VIII SMPN 16 Mataram Tahun Ajaran 2019/2020. Dalam penelitian ini peneliti menggunakan instrumen berupa angket dan tes essai. Sebelum melakukan pengambilan data, peneliti menguji validitas instrument angket dan tes kepada validator ahli. Setelah instrument dinyatakan valid oleh validator, maka angket motivasi berprestasi, angket persepsi siswa tentang cara guru mengajar dan soal tes dapat digunakan untuk pengambilan data. Pengambilan data dilakukan selama 2 minggu pada tanggal 12 februari 2020 sampai tanggal 24 februari 2020 . Untuk pengambilan data motivasi berprestasi dan persepsi siswa tentang cara guru mengajar diperoleh dari hasil kuesioner 110 siswa kelas VIII A, B, C, dan D SMPN 16 Mataram, sedangkan data hasil belajar diperoleh dari tes essai sebanyak 5 soal.

Untuk melihat bagaimana pengaruh motivasi berprestasi dan persepsi siswa tentang cara guru mengajar terhadap hasil belajar matematika siswa menggunakan uji korelasi dan uji regresi. Sebelum dilakukan analisis statistik inferensial, terlebih dahulu peneliti melakukan uji prasyarat yaitu berupa normalitas, linieritas dan multikolinieritas. Karena uji prasyarat telah memenuhi syarat maka dapat dilanjutkan ke uji korelasi dan regresi.

Pada hasil analisis korelasi parsial menunjukkan hubungan yang positif antara motivasi berprestasi terhadap hasil belajar matematika sisawa. Hal ini ditunjukkan dengan nilai koefisien korelasi yang positif sebesar 0,318 . Nilai koefisien korelasi yang positif menunjukkan bahwa semakin tinggi motivasi berprestasi maka semakin tinggi pula hasil belajar matematika siswa. Setelah dilakukan uji t diperoleh nilai Sig. Sebesar 0,001<0,05 sehingga dapat disimpulkan bahwa terdapat pengaruh yang signifikan motivasi berprestasi terhadap hasil belajar matematika siswa kelas VIII SMP Negeri 16 Mataram Tahun Ajaran 2019/2020. Persamaan garis regresinya yaitu $Y^{\wedge}=-3,378+0,611 X$ dengan besar pengaruh motivasi berprestasi terhadap hasil belajar matematika pada siswa kelas VIII SMP Negeri 16 Mataram Tahun Ajaran 2019/2020 yaitu sebesar 10,1\%.

Hasil penelitian ini sejalan dengan penelitian Andi (2017) bahwa motivasi berprestasi berpengaruh terhadap hasil belajar dengan besar kontribusi yaitu 49,5\%. Hasil penelitian ini didukung oleh teori yang dikemukakan oleh Purwanto (2013) yaitu motivasi berprestasi merupakan salah satu faktor yang ikut menentukan keberhasilan dalam belajar. Menurut Mc Clelland (Sahidin et al., 2013) mendefinisikan motivasi berprestasi sebagai suatu usaha untuk mencapai sukses, yang bertujuan untuk berhasil dalam kompetisi dengan suatu ukuran keunggulan. Oleh karena itu motivasi berprestasi siswa perlu ditingkatkan untuk meningkatkan hasil belajar siswa. Terbuktinya hipotesis pertama memberikan informasi bahwa motivasi berprestasi perlu ditingkatkan agar hasil belajar matematika siswa dapat meningkat pula. Cara yang 
bisa dilakukan untuk meningkatkan motivasi berprestasi antara lain guru harus menciptakan suasana belajar yang dapat meningkatkan motivasi berprestasi siswa, misalnya dengan pemberian nilai lebih bagi siswa yang aktif sehingga siswa akan tertarik mengikuti proses pembelajaran dan termotivasi untuk berprestasi. Selain itu, siswa harus lebih memperhatikan saat guru memberikan pelajaran, mencatat materimateri yang penting, serta lebih aktif ketika proses pembelajaran berlangsung sehingga motivasi berprestasi siswa semakin meningkat dan hasil belajar matematika yang dicapai siswa juga akan meningkat.

Selanjutnya, pada hasil analisis korelasi parsial menunjukkan hubungan yang positif antara persepsi siswa tentang cara guru mengajar terhadap hasil belajar matematika siswa. hal ini ditunjukkan dengan nilai koefisien korelasi yang positif sebesar 0,421. Nilai koefisien korelasi yang positif menunjukkan bahwa semakin tinggi persepsi siswa tentang cara guru mengajar maka semakin tinggi pula hasil belajar matematika siswa. Berdasarkan nilai uji $\mathrm{t}$ diperoleh nilai Sig. Sebesar $0,000<0,05$ sehingga dapat disimpulkan bahwa terdapat pengaruh yang signifikan persepsi siswa tentang cara guru mengajar terhadap hasil belajar matematika siswa kelas VIII SMP Negeri 16 Mataram Tahun Ajaran 2019/2020. Persamaan garis regresinya $Y^{\wedge}=-20,198+1,033 X$ dengan besar pengaruh persepsi siswa tentang cara guru mengajar terhadap hasil belajar matematika pada siswa kelas VIII SMP Negeri 16 Mataram Tahun Ajaran 2019/2020 yaitu sebesar 17,8\%.

Hasil penelitian ini sejalan dengan penelitian Ahmadi et al. (2017) bahwa persepsi siswa tentang cara guru mengajar berpengaruh terhadap hasil belajar matematika dengan besar kontribusi yaitu 9,5\%. Hasil penelitian ini didukug oleh teori yang dikemukakan oleh Purwanto (2013) bahwa salah satu faktor eksternal yang mempengaruhi hasil belajar adalah guru/pengajar atau cara guru mengajar. Menurut Desmita (2012) persepsi diawali dengan adanya rangsangan dari lingkngan sekitarnya yang ditangkap oleh panca indra, stimulus yang telah ditangkap kemudian akan diterjemahkan oleh otak untuk dapat menginterpretasikan dan menyaring informasi yang diperlukan. Hasil pemaknaan inilah yang membentuk persepsi individu. Dengan demikian dapat dikatakan bahwa semakain tinggi (positif) persepsi siswa tentang cara guru mengajar akan semakain tinggi pula hasil belajar matematika yang akan dicapai siswa.

Terbuktinya hipotesis tersebut juga memberikan informasi bahwa persepsi siswa tentang cara guru mengajar yang positif perlu ditingkatkan agar hasil belajar matematika dapat meningkat pula. Cara yang bisa dilakukan untuk membentuk persepsi siswa tentang cara guru mengajar yang positif antara lain guru menciptakan suasana belajar yang menyenangkan dalam proses pembelajaran agar siswa tidak jenuh.

Untuk melihat pengaruh motivasi berprestasi dan persepsi siswa tentang cara guru mengajar terhadap hasil belajar matematika siswa secara bersama-sama digunakan regresi berganda dengan uji F. Hasil uji F motivasi berprestasi dan persepsi siswa tentang cara guru mengajar terhadap hasil belajar diperoleh bahwa $H_{0}$ ditolak, hal ini 
berarti bahwa "terdapat pengaruh motivasi berprestasi dan persepsi siswa tentang cara guru mengajar terhadap hasil belajar matematika pada siswa kelas VIII SMP Negeri 16 Mataram Tahun Ajaran 2019/2020".

Selain itu terdapat hubungan yang positif antara motivasi berprestasi dan persepsi siswa tentang cara guru mengajar terhadap hasil belajar matematika, koefisien korelasi yang didapatkan termasuk dalam tingkat hubungan yang sedang. Hal tersebut dapat ditunjukkan dengan nilai koefisien korelasi sebesar 0,448 dan koefisien determinasi sebesar 20,1\%. Artinya motivasi berprestasi dan persepsi siswa tentang cara guru mengajar bersama-sama memberikan kontribusi terhadap hasil belajar matematika siswa sebesar $20,1 \%$ dan sisanya $79,9 \%$ ditentukan oleh faktor lain.

Menurut Purwanto (2013) selain motivasi berprestasi dan persepsi siswa tentang cara guru mengajar ada faktor lain yang mempengaruhi hasil belajar yaitu faktor internal atau dalam diri siswa (faktor jasmani dan faktor psikologi) dan faktor eksternal atau faktor dari luar siswa (faktor lingkungan dan faktor instrumental). Sehubungan dengan hal tersebut, maka dalam penelitian ini dapat dikatakan bahwa motivasi berprestasi dan persepsi siswa tentang cara guru mengajar bersama-sama mempunyai pengaruh yang signifikan terhadap hasil belajar matematika pada siswa kelas VIII SMP Negeri 16 Mataram walaupun sumbangan presentasenya sedang.

\section{SIMPULAN}

Berdasarkan hasil analisis data dan pembahasan dapat ditarik kesimpulan sebagai berikut:

a). Terdapat pengaruh yang signifikan motivasi berprestasi terhadap hasil belajar matematika pada siswa kelas VIII SMPN 16 Mataram Tahun Ajaran 2019/2020 dengan pengaruh sebesar 10,1\%.

b). Terdapat pengaruh yang signifikan persepsi siswa tentang cara guru mengajar terhadap hasil belajar matematika pada siswa kelas VIII SMPN 16 Mataram Tahun Ajaran 2019/2020 dengan pengaruh sebesar 17,8\%.

c). Terdapat pengaruh yang signifikan motivasi berprestasi dan persepsi siswa tentang cara guru mengajar terhadap hasil belajar matematika pada siswa kelas VIII SMPN 16 Mataram Tahun Ajaran 2019/2020 dengan pengaruh sebesar 20,1\%. Bagian ini memaparkan simpulan penelitian sesuai dengan hasil dan temuan penelitian. Bagian ini tidak perlu ada kutipan atas simpulan. Kesimpulan menggambarkan jawaban atas hipotesis dan / atau tujuan penelitian atau temuan ilmiah yang diperoleh. Kesimpulan tidak mengandung pengulangan hasil dan diskusi, melainkan merangkum temuan seperti yang diharapkan dalam tujuan atau hipotesis.

\section{REFERENSI}

Bimo, W. (2010). Pengantar psikologi umum. Yogyakarta: CV Andi.

Desmita. (2012). Psikologi perkembangan peserta didik. Bandung: Rosda Karya. 
Nasution, S. I. (2017). Analisis faktor-faktor yang berpengaruh terhadap motivasi berprestasi mahasiswa prodi manajemen pendidikan islam tarbiah dan keguruan UIN Raden Intan Lampung. Al-Idarah: Jurnal Kependidikan Islam, 7(2)

Priansa, D. J. (2017). Pengembangan strategi dan model pembelajaran. Bandung: CV Pustaka Setia

Sadirman, A.M. (2011). Interaksi dan motivasi belajar mengajar. Jakarta: Rajawali Pers.

Sahidin, Latief, \& Jamil, D. (2013). Pengaruh motivasi berprestasi dan persepsi siswa tentang cara guru mengajar terhadap hasil belajar matematika. Jurnal Pendidikan Matematika, $4(2)$

Slameto. (2010). Belajar dan faktor - faktor yang mempengaruhi. Jakarta: Rineka Cipta.

Purwanto, M. N. (2013). Psikologi pendidikan. Bandung: PT Remaja Rosdakarya. 